August 2008

\title{
Not in My Name: A Social Psychological Study of Antecedents and Consequences of Acknowledgment of In-Group Atrocities
}

Sabina Čehajić

Rupert Brown

\section{Recommended Citation}

Čehajić, Sabina and Brown, Rupert (2008) "Not in My Name: A Social Psychological Study of Antecedents and Consequences of Acknowledgment of In-Group Atrocities," Genocide Studies and Prevention: An International Journal: Vol. 3: Iss. 2: Article 5.

Available at: https://digitalcommons.usf.edu/gsp/vol3/iss2/5

This Articles is brought to you for free and open access by the Open Access Journals at Digital Commons @ University of South Florida. It has been accepted for inclusion in Genocide Studies and Prevention: An International Journal by an authorized editor of Digital Commons @ University of South Florida. For more information, please contact digitalcommons@usf.edu. 


\title{
Not in My Name: A Social Psychological Study of Antecedents and Consequences of Acknowledgment of In-Group Atrocities
}

\author{
Sabina Čehajić \\ Sarajevo School of Science and Technology, Bosnia and \\ Herzegovina
}

\author{
Rupert Brown \\ University of Sussex, UK
}

\begin{abstract}
This article is concerned with psychological reactions on the part of Serbian people to atrocities committed by their group. A study conducted in the aftermath of genocidal acts committed in Bosnia and Herzegovina between 1992 and 1995 explored the question of socio-psychological factors facilitating and obstructing individuals' readiness and willingness to acknowledge Serbian atrocities. Eighteen Serbian participants were interviewed in depth about their perceptions and feelings regarding their group's moral violations. The study found that, in general, participants were reluctant to acknowledge and prone to justify their group's misdeeds. Although avoidance of collective atrocities committed in the past was a pronounced psychological reaction, the study also found approach-related tendencies such as intergroup contact to facilitate acknowledgment. The implications of these psychological processes for reconciliation are discussed.
\end{abstract}

Keywords: genocide, acknowledgment, denial, intergroup reconciliation

\section{Introduction}

In July 1995, more than 8,000 Bosnian Muslim men and boys as young as seven were systematically massacred by Serbian forces in Srebrenica, two years after the town had been declared a UN 'safe zone.' The Srebrenica massacre became a symbol of the Bosnian war. On 26 February 2007, the International Court of Justice confirmed that the Srebrenica massacre was an act of genocide. The main suspect, Ratko Mladiá, is still at liberty, probably under the protection of the Serbian government. ${ }^{1}$ One might expect that Serbians would be happy finally to relinquish all accused war criminals to an international court, but this does not seem to be the case. Why?

In analyzing this need to protect one's own group and its members, social identity theory may be useful. ${ }^{2}$ This social psychological theory proposes that belonging to social groups constitutes an important aspect of the self. Further, it argues that, just as people strive to maintain a positive self-concept as individuals, they are also motivated to maintain or achieve a positive social identity, an evaluation of the in-group as better, superior, and worthy. In situations of atrocities committed by the in-group (as in Srebrenica), it would be plausible to expect that this need for positive social identity will be expressed through either denial or 
justification of the group's actions. Indeed, a common reaction to atrocities committed by the in-group is to repress, forget, or simply ignore the "unwelcome" information. ${ }^{3}$ To put it simply, a common reaction seems to be to deny. People seem to be able to find ways to deny the meaning of what they or members of their group have done, and it is these denials, according to Stanley Cohen, that not only obstruct any reconciliatory process but also allow atrocities to be committed in the first place. ${ }^{4}$ Living in a world in which refusal of acknowledgment and responsibility and a lack of adequate punishment for offender(s) are more common than truth and justice simply makes it easier to commit horrible acts against others and then deflect their meaning afterwards.

With these considerations in mind, we set out to investigate two questions. First, how do people deal psychologically with transgressions committed by their group, and, in particular, what are the socio-psychological conditions that might contribute to or undermine their readiness to acknowledge in-group malfeasance? Second, what happens after people have acknowledged at least some degree of group responsibility, and, in particular, what are their emotional reactions? To shed some light on these issues, we carried out an interview study with a small sample of Bosnian Serbs living in Bosnia and Herzegovina (BIH).

\section{The Importance of Acknowledgment}

Acknowledgment of group crimes has been identified as the main constitutive element of intergroup reconciliation. ${ }^{5}$ Although the rhetoric of reconciliation looks for tolerance, forgiveness, and social reconstruction rather than punishment, it is impossible to expect reconciliation if part of the population refuses to accept that anything was ever wrong or distorts the meaning of in-group actions. ${ }^{6}$ Collective and public truth telling is the first, if not the most important, process that paves the road toward a just and reconciled future. ${ }^{7}$ First, victims demand and value the truth. ${ }^{8}$ They desire, and need, to know exactly what has happened. People not have only a human right to learn the truth but also a psychological need to know. Second, there is a widely held view that perpetrators will never be able to heal from the wounds created by their actions so long as they choose to deny or justify their behavior. ${ }^{9}$ Finally, collective acknowledgment entails a notion of "never again"- the hope that exposure of past misdeeds will prevent their repetition in the future. Through acceptance of collective responsibility and provision of punishment, the likelihood of future atrocities is undermined. ${ }^{10}$ And yet, despite all these arguments as to why acknowledgment of collective crimes is an important feature of reconciled intergroup relations, little research has yet attempted to address the question of the psychological processes that might underlie this process. Consequently, one of the main aims of the study documented here was to explore the question of sociopsychological conditions that might facilitate or obstruct both acknowledgment of group responsibility for the suffering of others and the consequent psychological reactions.

Because the question of psychological predictors of collective acknowledgment has been little explored, we decided to explore this question phenomenologically, by interviewing members of a perpetrator group in depth about how they currently perceive, understand, and respond emotionally to transgressions committed by their group in the recent past. 


\section{Method}

\section{Participants}

The sample consisted of eighteen participants, eight female and ten male. All participants identified themselves as Serbs. Their mean age was twenty-nine years, with a range between twenty and fifty-one years. ${ }^{11}$ Five participants held a university degree, while a further nine were pursuing one. Eight participants reported being currently employed. All participants reported some contact with members of other nationalities within $\mathrm{BIH}$, and two reported experiencing direct harm or loss during the war.

Data were collected from ten different locations: Sarajevo, Banja Luka, Pale, Nevesinje, Čapljina, Han Pijesak, Bijeljina, Trebinje, Srebrenica, and Belgrade. Initially, the selection of participants was random. After an individual interview, each participant was asked whether he or she was aware of any specific person who might be informative for the purpose of the study. This "snowballing strategy" produced a pool of participants that was used for further data collection.

\section{Procedure and Interview Questions}

Recruitment of participants and data collection took place in two phases over a two-month period between October and December 2005. The first phase consisted of the collection of initial accounts, which were analyzed to construct a preliminary description of the study's purpose. On the basis of these preliminary data, additional participants were selected who were expected to expand and challenge the initial findings. The research process followed the iterative principle of data collection-analysis-data collection. ${ }^{12}$

Research participants were contacted either by telephone or by e-mail. The purpose of the study and the audio-recording procedure were explained. Because of participants' circumstances, three interviews were conducted by phone, using a cable for phone recording. None of those contacted refused to participate in the study. Once participants gave their consent, a brief questionnaire covering demographic information (gender, age, place of residence, level of education, employment, membership in NGOs, intergroup contact, and perceived degree of victimization) was administered before the interview.

Interviews took place in either offices or public facilities (mainly cafes). Apart from the researcher and the participant, nobody else was present during the interview process. The interview process (without the warm-up questions) lasted an average of about fifty minutes, ranging from twenty-five to ninety minutes. After an initial warmup and the introduction of the study's purpose, two open-ended questions were asked, each consisting of three themes:

(1) How do people (including you) in Bosnia and Herzegovina deal with atrocities committed by your own group ${ }^{13}$
(a) On the cognitive level
(b) On the emotional level
(c) On the behavioral level ${ }^{14}$

(2) What do you think about the processes of collective acknowledgment?

(a) What processes might contribute to or obstruct the development of collective acknowledgment? 
(b) What are the specific characteristics or experiences associated with people who are more willing (ready) to acknowledge the suffering of others for which their own group is responsible?

\section{Data Analysis}

As previously noted, the present study was an exploratory examination of how people deal with the past, and especially with atrocities committed by the in-group (on the cognitive, emotional, and behavioral levels); the study focused on identifying factors that may contribute to or obstruct the process of acknowledgment. To this end, four steps were used to analyze the qualitative data gathered through these semistructured interviews.

First, the audiotaped interviews were transcribed. An in-depth content analysis was then performed in order to define the themes emerging from the interviews. Once all interviews had been coded, data were sorted into narrower categories within each large theme, allowing for easier interpretation. ${ }^{15}$

Since this study was "discovery oriented," in the analysis we used constant comparison of coded interviews every time a new code appeared. Thus, when a new code did not fit into an initial domain (category), a new domain was created and similar codes were included. Through this process we allowed new patterns to emerge rather than imposing patterns on the data.

\section{Results}

The study results are presented below in two sections, each referring to the interview questions: (1) dealing with in-group atrocities and (2) acknowledgment of in-group atrocities. The first section is further divided into three levels-(a) cognitive, (b) emotional, and (c) behavioral-and the data are presented accordingly. Categories that emerged as a result of data analysis are presented according to their frequencies (categories mentioned by a majority of participants will be presented first, etc.). The second section has two subsections: negative and positive predictors of acknowledgment.

\section{Dealing with Atrocities Committed by the In-Group}

With respect to the question of how people deal with the knowledge of their group's moral violations, the data analysis located eleven categories, three of which referred to cognitive, five to emotional, and three to behavioral processes.

\section{The Cognitive Level}

On the cognitive level, participants' answers fell into three main categories: avoidance of dealing with atrocities committed by the in-group, use of various justificationcognitions, and inquiry-oriented tendencies capturing the need for more information about the past.

Avoidance: The majority of participants mentioned the need to forget everything that has happened in the past and, hence, everything their group might have done during the war. One participant reflected on his need to forget the Srebrenica massacre:

The best thing would be to forget everything. It is not easy to deal with it. We did not have an option to choose whether we wanted that war. I think we need to forget and move on. In principle, I don't like to think about Srebrenica for example." (Miro, ${ }^{16}$ male, 23) 
As the main reason for such a necessity to avoid or to forget the past, one participant mentioned the psychological uneasiness of facing in-group wrongdoing, which, in turn, might elicit some uncomfortable emotional states:

I think that psychologically it is very difficult to deal with the past. That is the reason why many young people simply avoid past- and war-related topics. (Dragana, female, 48)

Answers to the question of whether people should deal with in-group atrocities at all show opposing tendencies. One woman, for example, was very explicit in her opinion that people, and young people in particular, should not care at all about the misdeeds committed in their name:

Although I think that we will never be able to forget the past, I think that we should. Young people should not care about the past and about the misdeeds committed by some individuals. (Mira, female, 20)

On the other hand, another participant, while agreeing on the general and widespread collective orientation toward forgetting, made this comment:

Denial of our past, of our acts is evident. We do not talk about it at all. We do not communicate about things that are being discovered every day like mass graves. We have never raised a question of the war Milosevic was leading. Never. ... I think that people in general are not willing to deal with the past. But I think that each of us should. (Bojana, female, 28)

Justifications: When not avoiding or suppressing the painful knowledge of in-group actions, participants seemed to engage in various means of justification. As the most widely reported justification strategy, participants mentioned the tendency to minimize the harm experienced by victims, as in this example:

People are justifying the acts committed by their group. Sometimes, they even think that many of the stories told about the atrocities are either lies or exaggerations. (Gordan, male, 33)

When they do not minimize the consequences of the in-group's harmful behavior, people seem to be inclined to use a discourse of victimhood in order to legitimize that behavior. For example, one participant noted that perception of one's group's victimhood may decrease the necessity to come to terms with in-group transgressions:

People are justifying the acts committed in this war by things that have happened in the past. Everybody is blaming everybody. You can always find justifications and explanations for current behavior if you dig in the past. And people here remember the past very well. People here remember what happened here 1,000 years ago. Such a remembrance based on perceived and exclusive victimhood influences current behavior. Even today, kids in the schools are being confronted with atrocities Serbs experienced in World War II. That is how we build and create prejudice toward other groups. (Bojana, female, 28)

Inquiry: Although not many participants mentioned "approaching" the past as a current mindset of Serbian people in Bosnia, a few did report a need not only to engage in-group misdeeds but also to uncover "everything" that has happened. A man in his fifties mentioned "digging out the past" as the most important step toward a reconciled future:

We need to dig out every single atrocity committed here. We need to face it and deal with it. In general, the problem here is that we have never learned to deal with our past. 
We tend to put everything under the carpet. The most important thing right now is to dig out everything. (Momo, male, 51)

\section{The Emotional Level}

With respect to affective reactions to collective wrongdoing, participants reported various emotional states, now and in the past. These emotional reactions (ranked by frequency) included feelings of shame, anger, guilt, pity for the in-group, and sadness. Some participants also reported having no feelings at all about in-group atrocities.

Shame: Analysis revealed that participants' reported feelings of shame referred to three different types of shame:

(1) Explicit shame: This type of shame expression included accounts of explicit shame, using words such as feeling "ashamed" or "humiliated" because members of the in-group had committed wrongs in the past. People who expressed this explicit type of shame seem to be dissociating themselves from the in-group, indicating some disidentification with the group. These kinds of shame feelings also seem to be associated with cognitive avoidance, as outlined above. The following two examples illustrate such identity dissociation and the desire to avoid past-related issues:

When I think of these atrocities, I feel ashamed. That is the reason why I refuse to accept Serbian people as the only group I can identify with. Sometimes I feel ashamed for being a member of a Serbian group. (Nenad, male, 24)

I am ashamed. I feel like "a bad person" when somebody mentions Serbian atrocities. In that moment, I tend not to react. I don't react to it because I don't want to identify with it. I am also afraid of saying something related to that. (Maja, female, 26)

(2) Group-image shame: This type of shame feelings relates to the damaged reputation of the in-group. Several participants reported "feeling ashamed" because of the way their group is seen today by other people and the world:

Sometimes I feel ashamed for how other people look at us, what they might think of us.

But I don't feel any guilt. (Maja, female, 26)

In addition, a few participants used an image of "carrying a black mark" as a result of in-group misdeeds:

For me personally, Srebrenica is a big shame. I cannot believe that we allowed it to happen. Now I feel like we are all guilty, but we are not. It should not have happened.... Srebrenica is the biggest black mark in Serbian history. It has created a bad image of us in the world. Up to now, we have had a good history. Now, not anymore! ... Nobody respects us anymore. Now, we are the lowest of the low. (Miro, male, 23)

I think that other people think of us now as bad people. I know that we are not but at the same time I don't blame those who think so. It seems like we will always carry a mark because we are Serbs. (Milenko, male, 25)

(3) Essence-shame: This type of shame is derived from a perception of some flawed aspect of group identity. For example, some participants reported feeling ashamed because of the perception of their own group as aggressive or even stupid by nature:

Sometimes I think that we Serbs always have to fight with somebody. If we didn't fight with other people, we would fight with each other. (Miro, male, 23)

I think that we Serbs like to oppose in general. If everybody says that the earth is round, we will say that it isn't, even if we know that it is not true... I also think that 
we are pretty stupid people who like to seek revenge. Just look at us now. (Benjamin, male, 25)

Another participant reported feeling "less worthy" and "dirty," just because she is a Serb:

I feel horrible when people in Sarajevo expect me to apologize. I get a feeling like I am "dirty." I carry the feeling of being dirty and less worthy, and I don't even know why. It makes me say, like, "I won't do it again?" But what? What is it that I won't do again? What did I do? (Bojana, female, 28)

Anger: Anger was the second most frequently reported emotional reaction to the in-group's behavior. As with shame, participants' answers that included feelings of anger fell into three different categories:

(1) Anger against the out-group: Here anger derived from a perception that others regard Serbs as the only perpetrators and Bosnian Muslims as the only victims. An exclusive right to victim status claimed by the out-group seems to be the source of the anger:

The thing that annoys me is that Bosnian Muslims are presented to be the only victims. Like they are the only innocent ones. (Benjamin, male, 25)

I get very annoyed when Bosniaks start with their innocence and victimhood. Like "poor us." It makes me outraged. Their accentuation of their victimhood drives me crazy. (Bojana, female, 28)

(2) Anger due to in-group homogenization by the out-group: Besides the concern that only Serbs are seen as "perpetrators," the tendency by others to "homogenize" all Serbs was another trigger for anger:

I am angry because nobody mentions the atrocities committed by the other side. All that is talked about are Serbian misdeeds. I am also angry when people look at us like we are all the same. Like we are all guilty. (Danica, female, 21)

(3) Anger due to having experienced discrimination: The sense of being homogenized by the out-group was sometimes linked to an experience of discrimination:

I am angry because my ex-boyfriend broke up with me because I am a Serb. I think that it is not fair. I felt discriminated against on the basis of my name. It made me very angry. (Maja, female, 26)

Guilt: After shame and anger, group-based guilt was also reported. Feelings of guilt about the group's actions were described as a "burden on a shoulder." The following examples illustrate this phenomenon:

I feel like I am carrying a burden. I am confused and hurt. I feel guilty sometimes even though I have not done anything wrong. It is very difficult for me. I feel like we will always carry a burden of consequences. (Milenko, male, 25)

Sometimes I feel guilty even though I have not done anything wrong. I feel like I am carrying a heavy burden. I feel like I am carrying the consequences of my fellows' behavior. That is not fair. (Nenad, male, 24)

I was fighting for justice from the very beginning of the war. I was against the majority because I felt guilty. All my people stayed in Sarajevo, and I flew to Belgrade. I never wanted to identify with these people who did all these bad things. (Dragana, female, 48) 
Self-pity: In addition to emotional reactions to collective wrongdoing, a few participants reported feelings of pity for in-group members who had committed atrocities, which, like feelings of shame, seemed to lead to dissociation from the in-group:

These people who committed atrocities are sick. I am a Serb but I am very different than these sick people. I pity them. That is the reason why I do not identify very highly with Serbs in general. (Nenad, male, 24)

Sadness: The above-mentioned emotional states were those most frequently reported. However, some participants also reported feeling sad because their group has harmed others in the past:

I feel sad when I think about Srebrenica. But in principle, I don't think a lot about it. Serbs died as well. We are the biggest victims in this war. ... I don't feel guilty about it but I feel sad. I would not feel sad if these people who were killed in Srebrenica were soldiers. But they were innocent victims and therefore I feel sadness. (Miro, male, 23)

Although most participants mentioned at least one emotion as a consequence of realizing that their own group has done something wrong in the past, a few said they felt "nothing at all." These participants were also the ones who were not very keen on talking about the topic in general. Their answers tended to be short:

I don't know what to say. I don't know what I think about Srebrenica. I don't think or feel anything. I cannot answer that question. (Mira, female, 20)

\section{The Behavioral Level}

At the behavioral level, participants' answers related mainly to intergroup contact and fell into three main categories: intergroup anxiety, caution during contact encounters, and avoidance of the out-group.

Intergroup anxiety: The majority of participants mentioned either fear or other negative and uncomfortable emotional states with respect to either anticipated or actual encounters with out-group members. Such fear seems not only to be present during the encounter itself but also to serve as a major obstacle to pursuing contact in the first place. The following examples illustrate this point:

At the beginning of the contact I feel a bit anxious about the relationship. But with time, the anxiety decreases. At the end, the quality of the relationship depends on the person himself. ... Just after the Dayton Accords, people who were involved in the war felt fear. The general fear of encountering the members of the other group and talking about the past was widespread. (Momo, male, 51)

Sometimes I have a feeling that other people are afraid of us. (Milenko, male, 25)

Contact caution: Besides reporting fear of or anxiety about pursuing contact, participants also mentioned exercising caution during the encounter itself. Four participants expressed that they "pay attention" to what they are saying when encountering members of other groups, particularly when it comes to past atrocities:

When encountering other people, I am very cautious and slow in developing a good quality relationship. (Miro, male, 23)

I think that we are very cautious in pursuing contact and expressing our true opinions. If I said everything I think, then I might not have any friends anymore. (Benjamin, male, 25) 
I am very cautious with my behavior, looking not to hurt anybody, not to say anything wrong. (Vlado, male, 23)

Avoidance of the out-group: In addition to intergroup anxiety as an obstacle to and in contact, some participants also mentioned dehumanization as a reason for avoiding the out-group:

People from Pale [in the Republika Srpska] think that Muslims are not humans. That is what stops them from coming down to Sarajevo and encountering them.

(Gordana, female, 22)

I think that the biggest problem is that we categorize ourselves into us and them categories. Hence, we categorize the victims as "our" or "their" victims. We don't perceive "their" victims as humans at the first place. Since they are not "ours," they are less human. (Vlado, male, 23)

This suggests that, in order to reduce the distress created by in-group behavior, members of the perpetrator group may engage in devaluation of the victims. By perceiving them as less worthy, they may avoid any potential self-sanctioning.

\section{Summary}

The study findings suggest that people in general are not willing or ready to deal with their group's morally reprehensible behavior and that they therefore make use of various avoidance-related strategies. Once they do choose to become aware of and acknowledge their in-group's wrongdoing, however, various emotional reactions follow. Shame, anger, and guilt were the most frequently reported emotional states. On the behavioral level, intergroup anxiety and caution during intergroup contact were common reactions. See Table 1 for the summary of the findings.

Table 1. Dealing with Atrocities Committed by the In-Group*

\begin{tabular}{ll}
\hline Level of Analysis & Categories \\
\hline Cognitive & Avoidance \\
& Justification \\
& Inquiry \\
& Shame ("explicit"; "group-image"; "essence") \\
& Anger (out-group-oriented anger; "perceived homogeneity anger"; \\
& "experienced discrimination anger") \\
& Guilt \\
& Self-pity \\
& Sadness \\
& Intergroup anxiety \\
& Contact caution \\
Behavioral & Avoidance of the out-group \\
&
\end{tabular}

\footnotetext{
*Table 1 summarizes the main findings on possible psychological reactions to in-group misdeeds. We acknowledge that the categories reported above are neither exhaustive nor exclusive. For example, an individual can feel many emotions at the same time as well as exhibiting a variety of behavioral reactions.
} 


\section{Acknowledgment of Atrocities Committed by the In-Group}

\section{Negative Factors}

Participants' answers with respect to factors that might obstruct willingness or readiness to acknowledge the misdeeds committed by one's own group fell into six categories: moral justification of the group's behavior, euphemistic labeling, lack of empathy and perspective taking, nationalism (glorification of the in-group), anger toward the out-group because there has been "no acknowledgment by the other side", and fear of being excluded from one's own group.

Moral justifications: With respect to justifying the acts committed by the in-group, one participant made the following comment:

Some people truly believe that their group has not done anything wrong and hence there is no need to acknowledge it. Even if they are confronted with the facts of committed atrocities, they close their eyes or look for justification. For example, in Nevesinje you will often hear people saying, "We said goodbye to Bosnian Muslims while throwing flowers on them and singing." (Gordan, male, 33)

Euphemistic labeling: The way people label the past and everything that has happened seems to be just one of the many strategies of moral disengagement that they may employ. For example, labeling the past as a "civil war" might automatically justify the intentional character of group misdeeds, since-in a case of a civil war-those who committed atrocities may have been defending themselves rather than attacking. The following excerpt illustrates the importance of the way people label past events:

The majority of people in Republika Srpska don't accept "aggression" as the exact term for what happened here. They still consider it to have been the war. Refusing to accept "aggression" as the label for the past automatically prevents them from acknowledging the wrongdoing committed by their group. (Dragana, female, 48)

Lack of perspective taking: The tendency to deny, or at least justify, the in-group's misdeeds seems to be associated with an inability to take the perspective of the other side, which, in turn, reinforces the inability or unwillingness to acknowledge. The following examples illustrate this point:

The process that definitely prevents acknowledgment from taking place is the tendency to look at everything from their own perspective and from the angle of their own pain. (Gordan, male, 33)

It is very difficult to be objective. Everybody sees the past from their own perspective. Such an inability to take the perspective of the other prevents acknowledgment. (Miro, male, 23)

The inability to take the perspective of the other side is one of the biggest obstacles to acknowledgment. We tend to look at things only from our state of mind. (Benjamin, male, 25)

Nationalism: The presence of nationalism is not surprising, especially in situations of intergroup conflict. Such a tendency to nationalistic attitudes seems not only to contribute to the denial or justification of in-group atrocities but also to obstruct the process of acknowledgment:

A few years ago, I was not ready to accept that Serbs have done something wrong in the past. A few years ago, I was a big nationalist. Now not anymore. (Dusko, male, 26) 
Anger toward the out-group: As we have already seen, besides shame, anger was the most commonly reported feeling. With respect to acknowledging the group's atrocities, a significant number of participants mentioned that they are angry because "the other side is not being punished" or because "Serbs are perceived as the only perpetrators":

As long as the other sides are not being punished as well, Serbs will never acknowledge their deeds. We perceive other groups' not being punished as injustice. This feeling of injustice bothers us. Everybody has to be brought to justice. Not only Serbs.... A group will never accept and acknowledge as long as the injustice continues. And the injustice is continuing as long as Serbs are perceived to be the only guilty ones. (Milenko, male, 25)

This absence of "punishing the other side" makes people angry and less willing to acknowledge the atrocities committed by their own group. One participant said that "as long as the other side is not acknowledging their own atrocities, we won't do the same either." Acknowledgment of in-group misdeeds seems to be conditional on an equivalent acknowledgment by the out-group.

Fear of exclusion: Besides anger, a few participants reported fear of being excluded from their own group as the main obstacle to acknowledgment. Denial of the in-group's atrocities was currently a widespread and commonly accepted state of mind. Acknowledging the past would automatically present itself as an opposition to the commonly accepted group opinion. Opposing one's group's beliefs would bring the risk of exclusion:

If you express your opinion which is different from the one given by the majority, then you might be excluded from the group. Maybe that is the reason why people are afraid to acknowledge. People are afraid of having another opinion, a fear of opposing the current state of mind. (Benjamin, male, 25)

People who did show willingness to help the victims during the war were executed or simply excluded from the group. It requires courage to resist and think differently ... in my opinion, the process that presents a huge obstacle to the process of acknowledgment is the lack of individualism in these places. Generally, people have faith in their leaders and churches. The majority of people do not think for themselves. That is the reason why we live in denial. (Bojana, female, 28)

If I acknowledge, I might be excluded from my group. I won't be a part of the group anymore. If the majority is denying, then I am denying as well. I adapt myself to it. If you are different from the rest, then it is hard. (Ivana, female, 50)

In sum, moral disengagement strategies such as justification and euphemistic labeling, in-group glorification and lack of perspective taking, out-group-oriented anger, and fear of being excluded from one's own group appear to be the major obstacles to acknowledging one's own group's atrocities.

\section{Positive Factors}

On the topic of factors that might contribute to the process of acknowledgment, participants' answers fell into four main categories: knowledge about the past, intergroup contact, acknowledgment by the other side, and empathy for the victims.

Knowledge about the past: Knowledge of what actually happened appears to be pertinent in the process of acknowledgment:

First we have to know what exactly has happened before we can acknowledge it. There is a big difference between knowledge and acknowledgment. (Bojana, female, 28)

I think that the main reason for the denial is the lack of right information. People don't always know what has happened. (Danica, female, 21) 
Intergroup contact: The majority of participants also mentioned out-group contact as the crucial step toward acknowledgment of in-group misdeeds. Through contact one is confronted with the other side of the story, as reported by a participant who had met a woman from Srebrenica:

My own most effective dealing with the past was an encounter with a woman from Srebrenica. I simply met her and listened to her story. (Bojana, female, 28)

Apart from direct confrontation with the consequences of group atrocities, contact in itself seems to have beneficial effects on intergroup relations:

People who are more open to contact, who are ready to listen to the other side, who have traveled and seen the world, who are willing to accept the difference, are more willing to acknowledge and enter the process of reconciliation. (Momo, male, 51)

Three or four years ago I was not ready to acknowledge atrocities committed by Serbs. The thing that has changed me was contact. I have seen that some things I thought to be true were not exactly the way I thought. I realized that I have lived in a closed society all the time. Contact changed me. It opened me. (Milenko, male, 25)

Acknowledgment by the out-group: A factor that was reported to make a significant contribution to acknowledgment was some recognition by the other side:

Only when other groups accept responsibility, then I might be ready to do the same. (Milenko, male, 25)

I think if one acknowledges the loss and the pain experienced by Serbs, they will be more willing to acknowledge the loss and the pain of the other. (Bojana, female, 28)

I think that if somebody would pay a bit of attention to Serbian victims as well, that would mean a lot to them. They need to feel a bit respected as well. If we do so, they might be more ready to acknowledge their own misdeeds. (Srdjan, male, 23)

Acknowledgment by victims of the perpetrators' current situation might further the healing process by increasing the likelihood of acknowledgment by the perpetrators themselves.

Perspective taking: As already mentioned, encountering out-group members, seeking out information about the past, and being confronted with the other side of "the story" all seem to be pertinent in the process of acknowledging the misdeeds committed by one's own group. Such "effective" contact has a positive association with perspectivetaking ability, which participants mentioned as "a key factor" in the process of acknowledgment:

Encountering the other, taking the other's perspective and listening to other stories is the key solution to acknowledgment of the past. (Srdjan, male, 23)

For the acknowledgment to take place, a person needs to see things from the other angle. People who are nationalist are not open to interacting with the other and hence to taking the perspective of the other side. (Milenko, male, 25)

I tried to understand the other side. I try to see things from the angle of the other group. (Srdjan, male, 23)

Exposing perpetrators to the stories of survivors may facilitate perspective taking and, hence, empathy. In turn, this might increase psychological readiness to acknowledge the in-group's morally objectionable behavior. 
Table 2. Acknowledgment of In-Group Atrocities*

\begin{tabular}{ll}
\hline Positive Predictors & Negative Predictors \\
\hline Knowledge about the past & Moral justification \\
Intergroup contact & Euphemistic labeling \\
Acknowledgment of the out-group & Lack of perspective taking \\
Perspective taking & Glorification of the in-group \\
& Anger toward the out-group \\
& Fear of exclusion from group \\
\hline
\end{tabular}

*See note to Table 1.

\section{Summary}

knowledge about the past, intergroup contact, acknowledgment by the out-group, and perspective-taking all appear to facilitate acknowledgment of in-group wrongdoing. The findings are summarized in Table 2.

At the end of the interview, each participant was asked to describe a person who has come to acknowledge the suffering of others for which his or her group is responsible. Such a person was described as follows: A person who does know, and admits knowing, everything that has happened, and who thus "does not have a problem with acknowledging" in-group wrongdoing, "hears the other's stories, is open to contact, has traveled around the world and seen other places, communicates with others about the past, talks and interacts with people who have experienced some loss, has seen a concrete consequence of committed atrocities (e.g., destroyed buildings, mass graves), has the courage to think differently, has a certain degree of independence, is educated, does not hate other people, and is simply a happy person with no psychological issues."

\section{Discussion}

This study had two main goals: to explore and understand the socio-emotional processes of how people deal with atrocities committed by their own group, and to identify factors that might facilitate or hinder the process of acknowledging such collective misdeeds.

Overall, our findings show that people in general are not ready or willing to come to terms with collective atrocities. This finding is in line with current political statements made by Serbian officials in relation to Serbian atrocities committed in the former Yugoslavia, with the Turkish government's attitude toward the Armenian Genocide of the early twentieth century, and with many other post-genocidal contexts. ${ }^{17}$ Such avoidance seems to be reinforced by various negative emotional states (e.g., anger, shame, guilt, sadness) that can arise when a person realizes that the in-group has harmed others; by the use of various means of justification; and by the glorification of the in-group. This finding, albeit only qualitative, suggests that individuals who identify strongly with their group will be more prone to engage in denial of their group's misdeeds and, hence, less inclined toward acknowledgment and possible feelings of guilt and shame. According to social identity theory, people (particularly high identifiers) are more motivated to protect their group image and sustain positive social identity. ${ }^{18}$ Indeed, our recent work (conducted in the same 
context) shows that in-group identification is negatively correlated with both acknowledgment of in-group atrocities and collective emotions of guilt and shame. ${ }^{19}$

Besides avoiding the past, participants generally reported intergroup anxiety and caution during contact encounters as defining features of intergroup relations, which, in turn, had led not only to higher out-group avoidance and, potentially, to a failure to establish any common ground but also to an exclusive in-group orientation. People tended to talk mainly about their own group's losses and suffering (victimization and victimhood orientation).

It seems that a not uncommon reaction of members of a perpetrator group is to perceive that they, and not the victim group, have suffered the most. ${ }^{20}$ In intergroup conflict situations-as in Bosnia and Herzegovina-members of conflicting groups tend to generate various beliefs that help them cope with the situation. ${ }^{21}$ Such beliefs are usually biased, because strong motivations-such as preserving a positive social identity-often underlie information processing in conflict situations. ${ }^{22}$ And, indeed, one such societal belief is that of one's own victimization, the idea that "we" have suffered more than "they." Such claims about in-group victimhood may be regarded as a psychological coping strategy and serve the purpose of minimizing the in-group's role in the conflict while simultaneously undermining processes that might contribute to reconciliation. Indeed, research conducted in Northern Ireland shows that a belief that one's own group has suffered more (termed "competitive victimhood") is negatively associated with intergroup forgiveness. ${ }^{23}$

Although avoiding the past seems to be associated with avoidance of negative emotions as well as with lack of intergroup contact, our findings suggest positive effects of approach-oriented tendencies toward the past in the form of communication and information seeking, intergroup contact, and perspective-taking ability. The results of the study suggest that members of the perpetrator group who have some contact with members of the victim group may be more willing to acknowledge in-group crimes. Recent quantitative and narrative reviews have provided support for the "contact hypothesis," reaffirming favorable intergroup contact as a key variable in improving intergroup attitudes. ${ }^{24}$ Although no research to date has explicitly examined the effects of contact on acknowledgment, the results of the present study suggest that contact will be positively associated with other pro-social processes such as acknowledgment of in-group crimes. However, it is not contact per se that is expected to produce these beneficial effects but, rather, a contact situation characterized by at least some degree of trust and similarity. Recent research in $\mathrm{BIH}$ showed that high-quality contact situations facilitated forgiveness among members of the victim group. ${ }^{25}$

The underlying assumption that explains the beneficial effects of contact on acknowledgment is that being exposed to victims' stories, and hence to the "other perspective of the conflict," will increase empathic feelings and, at the same time, decrease both intergroup anxiety and the perception of in-group victimhood. Both empathy and anxiety have already been shown to mediate the effects of contact on attitudes toward the out-group. ${ }^{26}$ Therefore, it makes good theoretical sense that increased empathy and reduced anxiety should be implicated in eliciting readiness and willingness to acknowledge in-group crimes, since they promote a more relaxed and open appreciation of the other's current (distressed) emotional state. ${ }^{27}$

Although there are several limitations to this study, such as the use of a self-report approach and a small sample size, that undermine any causal inferences, it does provide useful information about how people deal with the past and with in-group 
committed atrocities (on the cognitive, emotional, and behavioral levels) as well as about factors that may have significant effects on the acknowledgment versus denial of group misdeeds, both of which are considered to be crucial steps toward the restoration of intergroup relations. Moreover, the study provides a solid framework from which researchers can begin to design further inquiries into the socio-emotional processes that contribute to the process of collective acknowledgment and acceptance of responsibility.

For some time it has been recognized that acknowledgment of responsibility for in-group moral violations and the suffering and pain inflicted on victims is the key element of successful intergroup reconciliation. ${ }^{28}$ How to facilitate these processes is still not clear, however. So far, the data from the present study suggest that good-quality contact situations can increase the likelihood of acknowledgment of in-group crimes.

Unfortunately, the current political structure of $\mathrm{BIH}$ does not lend itself to frequent intergroup contact, as the country is divided into two entities: the Federation of Bosnia and Herzegovina, populated mainly by Bosniaks and Croats, and the Republika Srpska, where Serbs are in the majority. Moreover, almost all government sectors, including the education system, operate at the level of these separate entities, which sometimes implies different priorities and different ways of achieving them. For example, schoolchildren may learn different and often opposing interpretations of the events of 1992-1995, depending on where they live. Such divisions within the country are not only detrimental to current intergroup relations but may also pave the road toward increased segregation in the future.

We believe that the present study has identified how people deal with the unwelcome knowledge of atrocities committed by their own group and what factors might contribute to a person's acknowledgment of atrocities committed in his or her name. As researchers, we hope that the data obtained through this study will be useful for both practitioners and future researchers interested in issues surrounding collective violence. Indeed, one direct benefit that has accrued from this qualitative research has been the development of reliable and valid quantitative measures of collective guilt and shame. ${ }^{29}$ We hope that others interested in promoting positive outcomes after severe intergroup conflicts will build on these first steps to arrive at a better understanding of the painful processes underlying people's acknowledgement of their in-group's misdeeds and acceptance of some personal responsibility for them.

\section{Notes}

1. “Genocide Ruling Frustrates Bosnia," BBC News, 27 February 2007, http://www.news. bbc.co.uk/2/hi/europe/6399319.stm (accessed 27 February 2007).

2. Henri Tajfel and John C. Turner, "The Social Identity Theory of Intergroup Behaviour," in Psychology of Intergroup Relations, ed. Stephen Worchel and William G. Austin, 7-24 (Chicago: Nelson Hall, 1986).

3. Stanley Cohen, States of Denial: Knowing about Atrocities and Suffering (Cambridge: Polity Press, 2001).

4. Ibid.

5. Margaret Gilbert, "Collective Remorse," in War Crimes and Collective Wrongdoing: A Reader, ed. Aleksandar Jokic, 216-35 (Oxford: Blackwell, 2001); J.P. Lederach, Building Peace: Sustainable Reconciliation in Divided Societies (Washington, DC: US Institute of Peace Press, 1997); Martha Minow, Between Vengeance and Forgiveness: Facing History after Genocide and Mass Violence (Boston: Beacon Press, 1998); Desmond Tutu, No Future Without Forgiveness (London: Rider, 1999). 
6. Cohen, States of Denial

7. Erwin Staub, "Reconciliation and the Prevention of Group Violence: From Rwanda and the Congo to Contemporary Terrorism" (paper presented at the annual meeting of the British Psychological Society, Kent University, 5-7 September 2007).

8. Tutu, No Future Without Forgiveness.

9. Michael Ignatieff, Blood and Belonging: Journeys into the New Nationalism (London: Vintage, 1994); Erwin Staub, "Reconciliation after Genocide, Mass Killing, or Intractable Conflict: Understanding the Roots of Violence, Psychological Recovery, and Steps Toward a General Theory," Political Psychology 27 (2006): 867-94; Tutu, No Future Without Forgiveness.

10. Cohen, States of Denial; Staub, "Reconciliation and the Prevention of Group Violence."

11. The selection of participants with such a wide age range was intentional. As this study was of an exploratory nature, we judged it appropriate to include both people who were adults during the 1992-1995 war, and hence have some clear memory of this period, and those who were children at that time and learned about their group's crimes after they had occurred.

12. D.E. Polkinghorne, "Narrative Configuration in Qualitative Analysis," International Journal of Qualitative Studies in Education 8 (1995): 5-23.

13. The reason for this tripartite division of participants' answers was simply to enable easier categorization of data. The participants were not directly asked to report how they deal with in-group atrocities on these three levels; they were simply asked to report their thoughts, perceptions, beliefs, and emotions about in-group crimes.

14. Answers that referred to current intergroup relations in BIH fell into this category.

15. Polkinghorne, "Narrative Configuration."

16. All names given here are pseudonyms. English translations of interview excerpts are by Sabina Cehajić.

17. Cohen, States of Denial.

18. Tajfel and Turner, "Social Identity Theory."

19. For acknowledgment see Sabina Čehajić, "Predictors of Acknowledgment" (unpublished manuscript, 2008); for collective emotions see Rupert Brown and Sabina Čehajić, "Dealing with a Past and Facing the Future: Mediators of Collective Guilt and Shame in Bosnia and Herzegovina," European Journal of Social Psychology 38 (2008): 669-84.

20. Daniel Bar-Tal and Gemma H. Bennink, "The Nature of Reconciliation as an Outcome and as a Process," From Conflict Resolution to Reconciliation, ed. Yaacov Bar-Siman-Tov, 11-38 (New York: Oxford University Press, 2004); Arie Nadler and Ido Liviatan, "Intergroup Reconciliation Process in Israel: Theoretical Analysis and Empirical Findings," in Collective Guilt: International Perspectives, ed. Nyla R. Branscombe and Bertjan Doosje, 216-35 (Cambridge: Cambridge University Press, 2004).

21. Daniel Bar-Tal, Shared Beliefs in a Society: Social Psychological Analysis (Thousand Oaks, CA: Sage Publications, 2000).

22. See, e.g., Marilynn B. Brewer and Rupert J. Brown, "Intergroup Relations," in The Handbook of Social Psychology, vol. 2, 4th ed. by Daniel T. Gilbert, Susan T. Fiske, and Gardner Lindzey, 554-94 (New York: McGraw-Hill, 1998).

23. M. Noor, R. Brown, and G. Prentice, "Predicting Intergroup Forgiveness between Protestants and Catholics in Northern Ireland Based on a Reconciliation Orientation Model," British Journal of Social Psychology, forthcoming.

24. For the "contact hypothesis" see Gordon W. Allport, The Nature of Prejudice (Cambridge, MA: Addison-Wesley, 1954); for quantitative review see Thomas F. Pettigrew and Linda R. Tropp, "A Meta-analytic Test of Intergroup Contact Theory," Journal of Personality and Social Psychology 90 (2006): 751-83. For narrative reviews see Rupert Brown and Miles Hewstone, "An Integrative Theory of Intergroup Contact," in Advances in Experimental Social Psychology, vol. 37, ed. Mark P. Zanna, 255-343 (London: Elsevier, 2005); Thomas F. Pettigrew, "Intergroup Contact Theory." Annual Review of Psychology 49 (1998): 65-85. 
25. Sabina Čehajić, Rupert Brown, and Emanuele Castano, "Forgive and Forget? Antecedents and Consequences of Intergroup Forgiveness in Bosnia and Herzegovina," Political Psychology 29 (2008): 351-67.

26. E.g., C. Daniel Batson, Marina P. Polycarpou, Eddie Harmon-Jones, Heidi J. Imhoff, Erin C. Mitchener, Lori L. Bednar, Tricia R. Klein, and Lori Highberger, "Empathy and Attitudes: Can Feeling for a Member of a Stigmatized Group Improve Feelings toward the Group?" Journal of Personality and Social Psychology 72 (1997): 105-18; Brown and Hewstone, "Integrative Theory"; Nurcan Ensari and Norman Miller, "The Out-Group Must Not Be So Bad After All: The Effects of Disclosure, Typicality, and Salience on Intergroup Bias," Journal of Personality and Social Psychology 83 (2002): 313-29; Mir Rabiul Islam and Miles Hewstone, "Dimensions of Contact as Predictors of Intergroup Anxiety, Perceived Out-Group Variability, and Out-Group Attitude: An Integrative Model," Personality and Social Psychology Bulletin 19 (1993): 700-710.

27. C. Daniel Batson, "Altruism and Prosocial Behavior," in The Handbook of Social Psychology, vol. 2, 4th ed. by Daniel T. Gilbert, Susan T. Fiske, and Gardner Lindzey, 282-310 (New York: McGraw-Hill, 1998).

28. Lederach, Building Peace; Tutu, No Future Without Forgiveness.

29. Brown and Čehajić, "Dealing with a Past." 